\title{
Effect of pre-sowing treatment of sunflower seeds on plant height and photosynthetic activity of hybrids F1 Borey And F1 Dariy under the conditions of the southwestern part of the Central Black Soil Region
}

\author{
Nadejda Kotsareva ${ }^{1}$, and Elena Kovalenko ${ }^{2}$ \\ ${ }^{1}$ Department of Biology, Belgorod State National Research University, Belgorod, Russia \\ ${ }^{2}$ Belgorod State Agricultural University named after V.Gorin
}

\begin{abstract}
The results of the research of the effect of seeds pre-sowing treatment with a complex of preparations, including protectant, microelements and growth regulators on economic and biological characteristics and properties of sunflower hybrids F1 Borey and F1 Dariy under conditions of the southwestern part of the Central Black Soil region are presented. The effective pre-sowing treatment scheme for seeds of sunflowers hybrids F1 Borey and F1 Dariy was determined, which allows us to obtain a seed yield up to $29.03 \mathrm{c} /$ ha (increasing $6.6 \mathrm{c} / \mathrm{ha}$ ) with a profitability level of $156.4 \%$ (increasing $39.6 \%)$.
\end{abstract}

\section{Introduction}

Stable price, sound liquidity made sunflower cultivation an attractive one. In the Belgorod region the average sunflower sowing area is $7 \%$ of all seeding-downs of this crop in the Russian Federation. The average yield in the Belgorod region is $21.2 \mathrm{c} / \mathrm{ha}$. To obtain high and sustainable sunflower yields pre-sowing seed treatment is one of the important backgrounds for profitable production.

According to many researchers $[1,2,3]$ the formation and deployment of one leaf takes about 3 days on average, which means that for 35 leaves formation the vegetation period is 105 days. The development of a sunflower plant comes to generative phase only after the formation on the cone maximum number of leaves for a given type. Therefore, in selection process mid- and fastgrowing cultivars one takes into account the number of leaves on a sunflower plant $[4,5]$.

In sunflower the role of each leaf canopies is different. Leaves from 12-15th to 23-25th leaves are distinguished by the highest photosynthetic activity, minimal water content and intensive assimilants outflow and play an important role in fat biocenosis in seeds [6, 7].

Researchers of the All-Union Scientific Research Institute of Oilseeds named after V.S. Pustovoit (AUSRIO) has proved that decreasing of five upper leaves size, the development of which stops before critical blossom begins, leads to increasing of droughtresistance and overcrowding tolerance $[8,10]$.

\section{Experimental}

The research was conducted at the Belgorod State Agricultural University named after V. Gorin during 2012-2014. The soil of the experimental ground plot is typical, medium-thick, heavy loamy black soils on loesslike clay loam soils.

The goal of the research was to study the effect of pre-sowing treatment of sunflower seeds on plants height and photosynthetic activity of hybrids F1 Borey and F1 Dariy in the conditions of the southwestern part of the Central Black Soil region.

The following tasks were set and solved: one has studied the effect of pre-sowing treatment with various solution of sunflower seeds on growth processes (plant height, photosynthetic activity), on economic and biological characteristics and immunological parameters of the hybrids F1 Borey and F1 Dariy in the southwestern part of the Central Black Soil region.

The experiment is two-factor: factor A is sunflower hybrids F1 Borey and F1 Dariy, factor B is treatment elements according to the scheme:

1. Without treatment - control

2. Vincite $21 / \mathrm{t}$

3. Maxim $5 \mathrm{l} / \mathrm{t}$

4. Maxim $5 \mathrm{l} / \mathrm{t}+$ Hydromix, $200 \mathrm{~g} / \mathrm{t}$

5. Maxim $5 \mathrm{l} / \mathrm{t}+$ radifarm, $0.2 \mathrm{l} / \mathrm{t}$

6. Maxim $5 \mathrm{l} / \mathrm{t}+$ fertigrain start, $1 \mathrm{l} / \mathrm{t}$

7. Maxim $51 / t+$ albit, $0.351 / t$

8. Maxim $51 / t+$ vympel (humate complex), $0.31 / t$

9. Maxim $5 \mathrm{l} / \mathrm{t}+$ hydromix, $200 \mathrm{~g} / \mathrm{t}+$ radifarm, $0.2 \mathrm{l} / \mathrm{t}$

10.Maxim $5 \mathrm{l} / \mathrm{t}+$ hydromix, $200 \mathrm{~g} / \mathrm{t}+$ fertigrain start, $11 / \mathrm{t}$

11.Maxim $5 \mathrm{l} / \mathrm{t}+$ hydromix, $200 \mathrm{~g} / \mathrm{t}+$ albit, $0.35 \mathrm{l} / \mathrm{t}$ 
12.Maxim 5 1/t t + hydromix, $200 \mathrm{~g} / \mathrm{t}+$ vympel (humate complex), $0.3 \mathrm{l} / \mathrm{t}$.

The total area of the registration plot is $25 \mathrm{~m}^{2}$, the total sowing area is $1800 \mathrm{~m}^{2}$ with triplicity tier. the sowing time of sunflower seeds is the third decade of april. the registration plots allocation in the experiment is randomized [3]. The predecessor is barley. fertilizers were not applied under the main treatment. sunflower dosing with complex fertilizer (azophoska at a dose of $100 \mathrm{~kg} \mathrm{d.m.} \mathrm{/} \mathrm{ha)} \mathrm{was} \mathrm{done} \mathrm{in} \mathrm{a} \mathrm{phase} \mathrm{of} \mathrm{2-3} \mathrm{leaves.} \mathrm{to}$ control weeds the lontrel-300 herbicide at a dose of 1 1/ha was used.

The following actions and observations were carried out in the experiment:

1. Phenological observations, counts and measurements - according to the method of state strain test of agricultural crops (1985).

2. The leaf-area duration of the plant - according to B.D. Dospehov [3].

3. Statistical analysis of experimental data - by the method of variance analysis of two-factor field experience on the ibm personal computer - intel pentium of the department of plant growing, selection and horticulture at the belgorod state agricultural university named after V. Gorin.

\section{Results and discussion}

During 3 year of the hybrids research on average, the length of sunflower stalk in the formation phase of two pairs of real leaves was 4-6 cm, in the phases of anthodium formation it was - 50-65 cm, in blossom phase it was $140-160 \mathrm{~cm}$. in plants of F1 Borey hybrid one has noted a significant effect of seeds pre-sowing treatment on plants height and, therefore, on photosynthetic activity and yield of the crop (table 1).

Pre-sowing treatment of sunflower seeds F1 Borey significantly contributed to the acceleration of plant growth processes. the height of sunflower plants in the experiment on average varied from $129.3 \mathrm{~cm}$ in the control to $162.5 \mathrm{~cm}$ in treatment option maxim $(5.01 / \mathrm{t})$ + hydromix $(200 \mathrm{~g} / \mathrm{t})+$ fertigrain $\operatorname{star}(1.01 / \mathrm{t})$.

The maximal height of sunflower plants F1 Borey was noted in $2012-171.3 \mathrm{~cm}$ in the option maxim (5.0 1 $/ \mathrm{t})+$ hydromix $(200 \mathrm{~g} / \mathrm{t})+$ fertigrain $\operatorname{star}(1.0 \mathrm{l} / \mathrm{t})$ ". the differences with control were $33.8 \mathrm{~cm}$.

In subsequent years, the height of sunflower plants was lower, but nevertheless the best option of presowing treatment was the option maxim $(51 / \mathrm{t})+$ hydromix $(200 \mathrm{~g} / \mathrm{t})+$ fertigrain star $(1 \mathrm{l} / \mathrm{t})$.

On average for 3 years the hybrid F1 Borey had maximal plant height in the options Maxim $(51 / t)+$ Hydromix $(200 \mathrm{~g} / \mathrm{t})+$ Fertigrain Star $(1 \mathrm{l} / \mathrm{t})$ and Maxim $(5 \mathrm{l} / \mathrm{t})+$ Hydromix $(200 \mathrm{~g} / \mathrm{t})+$ Albit $(0.35 \mathrm{l} / \mathrm{t})$, which was $32.4 \mathrm{~cm}$ and $30.2 \mathrm{~cm}$ higher than the control one.

The height of sunflower plants F1 Dariy was from $145.6 \mathrm{~cm}$ in the control to $169.4 \mathrm{~cm}$ in the option Maxim $(5 \mathrm{l} / \mathrm{t})+$ Hydromix $(200 \mathrm{~g} / \mathrm{t})+$ Fertigrain Star $(1 \mathrm{l} / \mathrm{t})$ (table 2).

The most intensive growth processes were founded with the application of the protectant Maxim (5 1/t) + Hydromix $(200 \mathrm{~g} / \mathrm{t})+$ Fertigrain Start $(1 \mathrm{l} / \mathrm{t})$.

The middle-early sunflower hybrid F1 Dariy has a leaf-area duration from 20.4 thousand $\mathrm{m}^{2} /$ ha to 23.5 thousand $\mathrm{m}^{2} /$ ha (table 4 ).

The maximum indicators of leaf-area duration were obtained in the option Maxim (5 1/t) + Hydromix (200 $\mathrm{g} / \mathrm{t})+$ Fertigrain Start $(1 \mathrm{l} / \mathrm{t})-3.1$ thousand $\mathrm{m}^{2} / \mathrm{ha}$.

Table 1. The effect of pre-sowing treatment on plant height of sunflower Hybrid F1 Borey

\begin{tabular}{|c|c|c|c|c|c|}
\hline \multirow[t]{2}{*}{ Plant treatment options } & \multicolumn{5}{|c|}{ Plant height, $\mathrm{cm}$} \\
\hline & 2012 & 2013 & 2014 & $\overline{\mathrm{X}}$ & \pm to the control \\
\hline Without treatment - control & 137,5 & 124,3 & 126,2 & 129,3 & - \\
\hline Vincite $(21 / t)$ - standard & 141,0 & 137,2 & 138,5 & 138,9 & +9 \\
\hline Maxim $(51 / \mathrm{t})$ & 143,5 & 131,5 & 141,4 & 138,8 & +9 \\
\hline $\operatorname{Maxim}(5 \mathrm{l} / \mathrm{t})+$ Hydromix $(200 \mathrm{~g} / \mathrm{t})$ & 151,5 & 131,5 & 138,1 & 140,4 & +11 \\
\hline $\operatorname{Maxim}(51 / \mathrm{t})+\operatorname{Radifarm}(0.21 / \mathrm{t})$ & 142,4 & 142,8 & 140,4 & 141,9 & +12 \\
\hline $\operatorname{Maxim}(51 / t)+$ Fertigrain $(11 / t)$ & 154,0 & 148,0 & 149,2 & 150,4 & +21 \\
\hline Maxim 5 1/t + Albit $(0.35$ l/t) & 150,7 & 157,2 & 153,8 & 153,9 & +24 \\
\hline $\operatorname{Maxim}(51 / \mathrm{t})+\operatorname{Vympel}(0.31 / \mathrm{t})$ & 148,5 & 138,5 & 141,5 & 142,8 & +13 \\
\hline $\operatorname{Maxim}(51 / \mathrm{t})+$ Hydromix $(200 \mathrm{~g} / \mathrm{t})+\operatorname{Radifarm}(0.21 / \mathrm{t})$ & 163,2 & 145,2 & 148,3 & 152,2 & +23 \\
\hline Maxim (5 l/t) + Hydromix (200 g/t) + Fertigrain Star (1 l/t) & 171,3 & 155,3 & 160,9 & 162,5 & +33 \\
\hline $\operatorname{Maxim}(5 \mathrm{l} / \mathrm{t})+$ Hydromix $(200 \mathrm{~g} / \mathrm{t})+\operatorname{Albit}(0.35 \mathrm{l} / \mathrm{t})$ & 169,0 & 153,1 & 155,7 & 159,3 & +30 \\
\hline $\operatorname{Maxim}(5 \mathrm{l} / \mathrm{t})+$ Hydromix $(200 \mathrm{~g} / \mathrm{t})+\operatorname{Vympel}(0.3 \mathrm{l} / \mathrm{t})$ & 162,8 & 142,4 & 147,1 & 150,7 & +21 \\
\hline \multicolumn{6}{|c|}{$\mathrm{HCP}_{05}-4,52$} \\
\hline
\end{tabular}


Table 2. The effect of pre-sowing treatment on plant height of sunflower Hybrid F1 Dariy

\begin{tabular}{|c|c|c|c|c|c|}
\hline \multirow[t]{2}{*}{ Plant treatment options } & \multicolumn{5}{|c|}{ Plant height, $\mathrm{cm}$} \\
\hline & 2012 & 2013 & 2014 & $\mathrm{X}$ & \pm to the control \\
\hline Without treatment - control & 157,2 & 139,4 & 140,1 & 145,6 & - \\
\hline Vincite (2 1/t) - standard & 163,8 & 147,2 & 146,3 & 152,4 & 6,8 \\
\hline $\operatorname{Maxim}(51 / \mathrm{t})$ & 165,2 & 143,9 & 143,8 & 150,9 & 5,3 \\
\hline $\operatorname{Maxim}(5 \mathrm{l} / \mathrm{t})+$ Hydromix $(200 \mathrm{~g} / \mathrm{t})$ & 178,1 & 157,8 & 156,2 & 164,0 & 18,4 \\
\hline $\operatorname{Maxim}(5 \mathrm{l} / \mathrm{t})+\operatorname{Radifarm}(0.2 \mathrm{l} / \mathrm{t})$ & 174,0 & 153,9 & 154,1 & 160,6 & 15,0 \\
\hline $\operatorname{Maxim}(5 \mathrm{l} / \mathrm{t})+$ Fertigrain $(1 \mathrm{l} / \mathrm{t})$ & 179,5 & 161,6 & 160,8 & 167,3 & 21,7 \\
\hline Maxim 5 l/t + Albit $(0.35$ l/t) & 175,0 & 160,2 & 162,0 & 165,7 & 20,1 \\
\hline $\operatorname{Maxim}(51 / \mathrm{t})+\operatorname{Vympel}(0.31 / \mathrm{t})$ & 168,0 & 146,0 & 144,8 & 152,9 & 7,3 \\
\hline $\begin{array}{c}\operatorname{Maxim}(5 \mathrm{l} / \mathrm{t})+\text { Hydromix }(200 \mathrm{~g} / \mathrm{t})+ \\
\text { Radifarm }(0.2 \mathrm{l} / \mathrm{t})\end{array}$ & 170,3 & 154,4 & 153,7 & 159,5 & 13,9 \\
\hline $\begin{array}{c}\text { Maxim }(5 \mathrm{l} / \mathrm{t})+\text { Hydromix }(200 \mathrm{~g} / \mathrm{t})+ \\
\text { Fertigrain Star }(1 \mathrm{l} / \mathrm{t})\end{array}$ & 182,0 & 163,3 & 162,9 & 169,4 & 23,8 \\
\hline $\begin{array}{c}\operatorname{Maxim}(5 \mathrm{l} / \mathrm{t})+\underset{(0.35 \mathrm{l} / \mathrm{t})}{\text { Hydromix }}(200 \mathrm{~g} / \mathrm{t})+\text { Albit } \\
\left(\mathrm{C}^{2}\right.\end{array}$ & 180,0 & 154,1 & 153,2 & 162,4 & 16,8 \\
\hline $\begin{array}{c}\text { Maxim (5 1/t) + Hydromix }(200 \mathrm{~g} / \mathrm{t})+ \\
\text { Vympel }(0.31 / \mathrm{t})\end{array}$ & 168,8 & 149,8 & 142,2 & 153,6 & 8,0 \\
\hline \multicolumn{6}{|c|}{$\mathrm{HCP}_{05}=11,07$} \\
\hline
\end{tabular}

Table 3. The effect of pre-sowing treatment on leaf-area duration of sunflower F1 Borey

\begin{tabular}{|c|c|c|c|c|c|}
\hline \multirow[t]{2}{*}{ Plant treatment options } & \multicolumn{5}{|c|}{ leaf-area duration, thousand $\mathrm{m} 2$ / ha } \\
\hline & 2012 & 2013 & 2014 & $\bar{X}$ & \pm to the control \\
\hline Without treatment - control & 18,7 & 16,2 & 16,6 & 17,2 & - \\
\hline Vincite $(21 / \mathrm{t})$ - standard & 19,0 & 17,7 & 18,0 & 18,2 & $+1,0$ \\
\hline $\operatorname{Maxim}(51 / \mathrm{t})$ & 19,2 & 17,5 & 18,4 & 18,4 & $+1,2$ \\
\hline $\operatorname{Maxim}(5 \mathrm{l} / \mathrm{t})+$ Hydromix $(200 \mathrm{~g} / \mathrm{t})$ & 19,6 & 17,8 & 18,7 & 18,7 & $+1,5$ \\
\hline $\operatorname{Maxim}(51 / \mathrm{t})+\operatorname{Radifarm}(0.21 / \mathrm{t})$ & 19,5 & 17,2 & 18,3 & 18,3 & $+1,1$ \\
\hline $\operatorname{Maxim}(51 / \mathrm{t})+$ Fertigrain $(1 \mathrm{l} / \mathrm{t})$ & 20,4 & 18,3 & 19,2 & 19,3 & $+2,1$ \\
\hline Maxim 5 1/t + Albit $(0.35$ l/t) & 20,4 & 18,8 & 19,5 & 19,6 & $+2,4$ \\
\hline Maxim $(51 / \mathrm{t})+\operatorname{Vympel}(0.31 / \mathrm{t})$ & 20,0 & 17,7 & 18,3 & 18,7 & $+1,5$ \\
\hline $\operatorname{Maxim}(5 \mathrm{l} / \mathrm{t})+$ Hydromix $(200 \mathrm{~g} / \mathrm{t})+\operatorname{Radifarm}(0.2 \mathrm{l} / \mathrm{t})$ & 20,5 & 19,2 & 19,4 & 19,7 & $+2,5$ \\
\hline $\operatorname{Maxim}(5 \mathrm{l} / \mathrm{t})+$ Hydromix $(200 \mathrm{~g} / \mathrm{t})+$ Fertigrain Star $(1 \mathrm{l} / \mathrm{t})$ & 21,3 & 20,6 & 19,8 & 20,6 & $+3,4$ \\
\hline $\operatorname{Maxim}(5 \mathrm{l} / \mathrm{t})+$ Hydromix $(200 \mathrm{~g} / \mathrm{t})+\operatorname{Albit}(0.35 \mathrm{l} / \mathrm{t})$ & 20,9 & 19,4 & 18,7 & 19,6 & $+2,4$ \\
\hline $\operatorname{Maxim}(5 \mathrm{l} / \mathrm{t})+$ Hydromix $(200 \mathrm{~g} / \mathrm{t})+$ Vympel $(0.3 \mathrm{l} / \mathrm{t})$ & 19,7 & 18,9 & 18,5 & 19,0 & $+1,8$ \\
\hline $\mathrm{HCP}_{05}=0,50$ & & & & & \\
\hline
\end{tabular}

Table 4. The effect of pre-sowing treatment on leaf-area duration of sunflower F1 Dariy

\begin{tabular}{|c|c|c|c|c|c|}
\hline \multirow{2}{*}{ Plant treatment options } & \multicolumn{5}{|c|}{ leaf-area duration, thousand $\mathrm{m} 2$ / ha } \\
\hline & 2012 & 2013 & 2014 & $\mathrm{X}$ & \pm to the control \\
\hline Without treatment - control & 21,0 & 19,7 & 20,4 & 20,4 & - \\
\hline Vincite $(21 / t)$ - standard & 22,1 & 21,4 & 20,9 & 21,5 & 1,1 \\
\hline $\operatorname{Maxim}(51 / \mathrm{t})$ & 22,2 & 21,6 & 21,3 & 21,7 & 1,3 \\
\hline $\operatorname{Maxim}(5 \mathrm{l} / \mathrm{t})+$ Hydromix $(200 \mathrm{~g} / \mathrm{t})$ & 22,7 & 21,3 & 22,4 & 22,1 & 1,7 \\
\hline $\operatorname{Maxim}(51 / \mathrm{t})+\operatorname{Radifarm}(0.2 \mathrm{l} / \mathrm{t})$ & 22,5 & 20,8 & 21,2 & 21,5 & 1,1 \\
\hline Maxim (5 1/t) + Fertigrain (1 1/t) & 23,4 & 22,5 & 22,7 & 22,9 & 2,5 \\
\hline Maxim 5 l/t + Albit $(0.35$ l/t) & 23,1 & 22,8 & 23,6 & 23,2 & 2,8 \\
\hline Maxim $(51 / \mathrm{t})+\operatorname{Vympel}(0.31 / \mathrm{t})$ & 23,0 & 21,5 & 22,8 & 22,4 & 2,0 \\
\hline Maxim (5 l/t) + Hydromix (200 g / t) + Radifarm (0.2 l/t) & 24,6 & 20,9 & 20,4 & 22,0 & 1,6 \\
\hline $\operatorname{Maxim}(5 \mathrm{l} / \mathrm{t})+$ Hydromix $(200 \mathrm{~g} / \mathrm{t})+$ Fertigrain Star $(1 \mathrm{l} / \mathrm{t})$ & 25,5 & 22,6 & 22,3 & 23,5 & 3,1 \\
\hline $\operatorname{Maxim}(5 \mathrm{l} / \mathrm{t})+$ Hydromix $(200 \mathrm{~g} / \mathrm{t})+\operatorname{Albit}(0.35 \mathrm{l} / \mathrm{t})$ & 25,1 & 21,7 & 22,9 & 23,2 & 2,8 \\
\hline $\operatorname{Maxim}(5 \mathrm{l} / \mathrm{t})+$ Hydromix $(200 \mathrm{~g} / \mathrm{t})+\operatorname{Vympel}(0.3 \mathrm{l} / \mathrm{t})$ & 23,4 & 21,3 & 22,4 & 22,4 & 2,0 \\
\hline \multicolumn{6}{|l|}{$\mathrm{HCP}_{05}=1,22$} \\
\hline
\end{tabular}




\section{Conclusion}

Thus, pre-sowing treatment of sunflower seeds with a complex of protective and growth-stimulating solutions maximally contributed to realization of plant adaptability potential and the strong plant stand formation. The growth potential of sunflower hybrids under research was significantly activated in the option Maxim (5 l/t) + Hydromix (200 g/t) + Fertigrain Star (1 1/t), which allowed us to choose this seed treatment as an optimal one.

\section{References}

[1] Alabushev V.A., Alabushev A.V. and other. Crop production: textbook / Ed. V.A. Alabusheva. (Publishing center "Mart", Rostov-on-Don, 2001).

[2] Korenev G.V. Plant growing with the basics of selection and seed production / G.V. Korenev, P.I. Podgorny, S. N. Shcherbak. (Agripromed, Moscow, 1990)

[3] Nichiporovich A. A Physiology of photosynthesis and plant productivity / A. A Nichiporovich // Photosynthesis physiology(Science, Moscow, 1982)
[4] Kolomeychenko V.V. Plant growing / V.V. Kolomeychenko (Agribusiness Center, Moscow, 2007)

[5] Konovalov J. B. Private selection of field crops / J. B. Konovalov, L.I. Dolgodvorova, L.V. Stepanova and others. (Agriprom-ed., Moscow, 1990)

[6] Vasilieva N. G. About sunflower photoperiodism // Physiological resistance of winter, spring breads and sunflower (VASKHNIL 56-76, 1936).

[7] Kurets V. K. Methods for the determination of certain biometric indicators in plants / V. K. Kurets.( Kar. Phil. USSR Academy of Sciences, Petrozavodsk, 1988)

[8] Maysuryan N.A. Crop Production / Under ed. V. N Stepanova and V. I. Lukyanuk. (Kolos, Moscow, 1971)

[9] Semikhnenko P.G. Sunflower / P.G. Semikhnenko, A.I. Klyuchnikov, T.M. Tokarev and others(Kolos, Moscow, 1965)

[10] Dospehov B.A. The methodology of field experiments (with the basics of statistical processing of the research results) / B.A. Dospekhov (Demand Book, Moscow, 2012) 